\title{
PROFILE OF BRAZILIAN DISSERTATIONS AND THESES ABOUT THE CORTISOL AS A STRESS MARKER
}

\author{
PERFIL DAS DISSERTAÇÕES E TESES BRASILEIRAS ACERCA DO CORTISOL \\ COMO MARCADOR DE ESTRESSE
}

\section{Pétala Tuani Candido de Oliveira SALVADOR ${ }^{1}$; Cláudia Cristiane Filgueira Martins RODRIGUES ${ }^{2}$; Marta Silvanêre PEREIRA ${ }^{3}$; Viviane Euzébia Pereira SANTOS ${ }^{4}$}

1. Enfermeira, Doutoranda em Enfermagem, Professora da Escola de Saúde da Universidade Federal do Rio Grande do Norte - UFRN, Natal, RN, Brasil. petalatuani@ hotmail.com; 2. Enfermeira, Doutoranda em Enfermagem, Professora da Escola de Saúde da UFRN, Natal, RN, Brasil. claudiacrisfm@yahoo.com.br; 3. Enfermeira, Graduada pela UFRN, Natal, RN, Brasil.

marta_silvanere@ hotmail.com; 4. Enfermeira, Doutora em Enfermagem, Professora do Departamento de Enfermagem da UFRN, Natal, RN, Brasil. vivianeepsantos@gmail.com.

\begin{abstract}
To Identify in dissertations and theses available on Brazilian Theses database of Coordenação de Aperfeiçoamento de Pessoal de Nível Superior (CAPES) information about the effects of cortisol as marker of stress; characterize the sample of the study. Study of literature review narrative, descriptive, the data were collected in February 2013, in pairs, following the research protocol previously established. There were analyzed 89 dissertations and theses in the light of the pillars: academic level; place of the study development; year; author's formation; the study population; the generator element of stress; and material analyzed. The majority of the studies denoted a significant change on the cortisol level through exposure to stress generator element $(74 ; 83.1 \%)$, revealing that this is a good marker of response to stress. It was noticed that there is a need to promote the development of clinical research with human beings, especially as health professionals.
\end{abstract}

KEYWORDS: Hydrocortisone. Stress, Physiological. Health Research Evaluation.

\section{INTRODUCTION}

Stress is present in our everyday actions and relations with society. It is the physiological response element to environmental stimuli. However, nowadays, this term has been used to determine a number of negative behavioral reactions, which disrupt the homeostasis of the human organism.

However, it should be emphasized that stress is triggered in all situations that the physical body understands it as a stressful stimulus. The concept of stressor stimulus was developed from the principle of external forces those produce transient or permanent changes on the individuals. These forces are considered events called stressors. Thus, the stress began to be considered a (physiological, cognitive or motor) response of the individual before a given stimulus (JOCA; PADOVAN; GUIMARÃES, 2003).

This stressor stimulus can be positive, as an element that motivates us to accomplish a particular task, as also can be negative, as in the case of an excess of activities in the workplace. These elements generate a physiological response in the body of stress mediated by the hypothalamuspituitary-adrenal (HPA) autonomic nervous system (ANS) and the shaft.
The ANS is responsible for immediate responses to stressors, altering the physiological state of homeostasis through direct influence in target organs. He gets the rush of adrenaline and noradrenaline that the stressor element triggered by receiving the immediate response to the stressor event (JOCA; PADOVAN; GUIMARÃES, 2003).

Already, the stimulation of the HPA axis determines a more prolonged response in the human body. The exposure to the stressor activates the secretion of releasing hormones, such as corticotropin (CRF) and adrenocorticotropic hormone $(\mathrm{ACTH})$, which in turn, will act in the cortex of the adrenal gland starting the synthesis and release of glucocorticoids, among these, which deepens, is cortisol in humans (JOCA; PADOVAN; GUIMARÃES, 2003; SILVA; MACEDO, 2011).

The circulating glucocorticoids promote the mobilization of stored energy and enhance numerous effects mediated by the sympathetic. Cortisol provides fuel for the battle (fight or flight), whose aim is to increase the sugar content in the blood, so that we have energy for action (CRUZ et al., 2012; SILVA; MACEDO, 2011).

The glucocorticoids, mainly cortisol, generate a series of metabolic effects that assess the harmful nature of the stress state. And these changes are fundamental to the understanding and success of 
the adaptive process as it increases the availability of energy and metabolism support.

Cortisol is responsible for $95 \%$ of glucocorticoid activity, being an indicator of stress, which can be determined through blood, urine or saliva. Therefore, this substance is regarded as the stress hormone, an imperative marker of this phenomenon (CRUZ et al., 2012; SILVA; MACEDO, 2011).

However, chronic activation of this stress response can lead to numerous diseases due to prolonged contact of the organism with this hormone, which can generate a constant activation of this state of stress in the body, determining the origin of a number of pathological stress, such as tachycardia, stomach pain, physical weakness, chronic fatigue, depression and physical body exhaustion (JOCA; PADOVAN; GUIMARÃES, 2003).

Given the above, it can be considered an event of stress rise complex in the body of the individual, because it is related to various causes and can generate multiple effects on the body. Moreover, one can consider the cortisol as a relevant marker of phenomena that stress may trigger man being highlighted its importance to the expansion of knowledge about the effects of stress on the human and animal organism.

Thus, based on the relevance that stress has on the body's physiology, as well as the consequences that these may trigger, and also emphasizing the importance of research as a guiding tool for new discoveries and influences of these elements in the human being, as if demarcating issues guiding the research: 1) What are the characteristics of the dissertations and theses available in Brazilian theses Database Coordination of Improvement of Higher Education Personnel (CAPES) that deal with cortisol as a marker of stress? 2) Such as cortisol as a marker of stress has been addressed in scientific studies?

It was chosen as the object of study of this research, dissertations and theses available in the Brazilian Theses database of CAPES that discussed on the thematic. The choice of such modes of scientific work was given by these investigations for research and reflection are characterized by their: personality, addressing issues experienced in a meaningful way by the investigator; autonomy, the result of the efforts of the author, creativity, resulting in collaboration with the development of science, and rigor, assuming logicality and competence (SEVERINO, 2007).

Therefore, this study was undertaken to Identify in dissertations and theses available on
Brazilian Theses database of Coordenação de Aperfeiçoamento de Pessoal de Nível Superior (CAPES) information about the effects of cortisol as marker of stress; characterize the sample of the study

\section{MATERIAL AND METHODS}

The data collection was performed in February 2013, by a couple of researchers, following the research protocol previously established. The protocol entitled "Protocol for Documentary Research", was composed of the following elements: theme, goal, guiding questions, search strategies, study selection, data collection strategy, strategy for critical evaluation of the studies and data synthesis.

We searched in the Theses database of CAPES, using the controlled descriptors 'cortisol' and 'physiological stress', in combination, in the search field 'subject', through 'all the words' option.

As inclusion criteria, there were selected the theses and dissertations available electronically at the Theses database of CAPES that discussed about cortisol as a marker of stress, excluding those that did not cover relevant to the scope of the research topic.

After collecting data, the selected theses and dissertations were submitted to critical analysis, by a couple of researchers, by creating a database in Microsoft Excel 2010, including the following categories of analysis with their respective standardizations:

- Academic level: indicated in the portal, specifying whether academic master's, professional master's or doctoral degree;

- Local Development Study: name of university/college;

- Year of publication: indicated in the portal;

- Training Author: according lattes curriculum;

- Study population: according to the categories birds, humans, fish, sheep, horses, mice, cattle, cats, amphibians, buffaloes, pigs, deer, bats, goats and monkeys;

- Generator element of stress: according to type thermal changes, chemical, physical exhaustion, containment, disease, feeding, harsh environment, labor, electrical stimulation, competition/training and changing patterns of behavior;

- Material examined: indicated if cortisol was analyzed from plasma, saliva or feces and there was additional material stress assessment. 
Beyond those categories of quantitative analysis, the abstracts were also assessed qualitatively according to the results elucidated with the research developed.

For a better presentation of the results, multiple form exposure data will be used, including the use of tables and charts, in addition to critical analysis of results according to the literature.

\section{RESULTS}

Table 1. Quantitative description of the results of the documentary research, according to the year, the academic level and the formation of the author, in absolute numbers, 2013.

\begin{tabular}{|c|c|c|c|c|c|c|c|c|c|c|c|c|c|c|c|c|}
\hline \multirow[b]{2}{*}{$\begin{array}{c}\text { Yea } \\
\mathbf{r}\end{array}$} & \multicolumn{3}{|c|}{ Level } & \multicolumn{13}{|c|}{ Formation of the author } \\
\hline & $\begin{array}{l}\mathbf{A} \\
\mathbf{M}\end{array}$ & $\begin{array}{l}\mathbf{P} \\
\mathbf{M}\end{array}$ & D & $\begin{array}{c}\text { Bi } \\
\mathbf{0}\end{array}$ & $\begin{array}{c}\mathbf{A g} \\
\mathbf{r} \\
\mathbf{S c i}\end{array}$ & $\begin{array}{c}\text { Bi } \\
\text { o } \\
\text { Sci }\end{array}$ & $\begin{array}{c}\text { Phy } \\
\text { Ed } \\
\text { u }\end{array}$ & $\begin{array}{c}\mathbf{A g} \\
\mathbf{r} \\
\text { En } \\
\mathbf{g}\end{array}$ & $\begin{array}{c}\text { Ch } \\
\text { e } \\
\text { En } \\
\text { g }\end{array}$ & $\begin{array}{c}\mathbf{P h} \\
\mathbf{a}\end{array}$ & $\begin{array}{c}\text { Physi } \\
\text { o }\end{array}$ & $\begin{array}{c}\text { Me } \\
\text { d }\end{array}$ & $\begin{array}{c}\text { Vet } \\
\text { Me } \\
\text { d }\end{array}$ & $\begin{array}{c}\text { Den } \\
t\end{array}$ & $\begin{array}{c}\text { Psy } \\
\text { c }\end{array}$ & $\begin{array}{c}\text { Zo } \\
\text { o }\end{array}$ \\
\hline 1995 & - & - & 1 & - & - & - & - & - & - & - & - & - & 1 & - & - & - \\
\hline 1996 & - & - & - & - & - & - & - & - & - & - & - & - & - & - & - & - \\
\hline 1997 & 1 & - & 1 & - & - & 1 & - & - & 1 & - & - & - & - & - & - & - \\
\hline 1998 & - & - & - & - & - & - & - & - & - & - & - & - & - & - & - & - \\
\hline 1999 & 1 & - & - & - & - & - & 1 & - & - & - & - & - & - & - & - & - \\
\hline 2000 & - & - & 2 & - & - & - & - & - & - & - & - & - & 1 & - & - & 1 \\
\hline 2001 & 7 & - & 3 & - & - & 4 & 1 & - & - & 1 & - & - & 3 & - & - & 1 \\
\hline 2002 & 3 & - & 1 & - & - & 2 & - & - & - & - & - & - & 1 & - & - & 1 \\
\hline 2003 & 5 & - & 1 & - & 1 & 1 & 1 & - & - & 1 & - & 1 & - & - & - & 1 \\
\hline 2004 & 5 & - & 1 & - & - & 3 & 1 & - & - & - & - & - & 1 & - & - & 1 \\
\hline 2005 & 4 & - & 4 & - & 1 & 2 & - & - & - & 2 & - & - & 3 & - & - & - \\
\hline 2006 & 4 & - & 4 & 1 & - & 2 & 1 & - & - & - & - & - & 3 & - & 1 & - \\
\hline 2007 & 7 & - & 1 & - & - & 2 & 1 & - & - & - & - & - & 1 & - & - & 4 \\
\hline 2008 & 4 & - & - & - & - & 1 & 1 & - & - & - & 1 & - & - & - & - & 1 \\
\hline 2009 & 3 & 1 & 5 & - & - & 3 & 1 & - & - & - & - & - & 3 & 1 & - & 1 \\
\hline 2010 & 7 & - & 5 & - & - & 4 & 1 & - & - & - & 1 & - & 2 & - & - & 4 \\
\hline 2011 & 4 & - & 4 & - & - & 1 & 3 & 1 & - & - & 1 & - & 1 & - & - & 1 \\
\hline Tota & 55 & 1 & 3 & 1 & 2 & 26 & 12 & 1 & 1 & 4 & 3 & 1 & 20 & 1 & 1 & 16 \\
\hline
\end{tabular}

Notes: $\mathrm{AM}=$ Academic Masters; $\mathrm{PM}=$ Professional Masters; $\mathrm{D}=$ Doctorate $;$ Bio = Biomedicine; Agr Sci = Agronomical Sciences; Bio Sci = Biological Sciences; Phy Edu = Physical Education; Agr Eng = Agricultural Engineering; Che Eng = Chemical Engineering; Pha = Pharmacy; Physio = Physiotherapy; Med = Medicine; Vet Med = Veterinary Medicine; Dent $=$ Dentistry; Psyc = Psychology; Zoo = Zootechny.

The temporal dimension of dissertations and theses ranged from 1995 to 2011 . The year 2010 had the highest number of productions, with $12(13,5 \%)$ investigations.

Regarding the academic level, there were analyzed $56(62,9 \%)$ dissertations and $33(37,1 \%)$ theses. Of total dissertations analyzed, $55(98,2 \%)$ were due to academic master and only one study $(0,8 \%)$ was the product of professional master's degree, which was defended in 2009. These figures also reveal the paucity of existing master courses in
Brazil, which are, gradually growing in scientific circles.

The researches which used cortisol as a marker of stress were developed primarily by researchers with initial training of Biological Sciences (26; 29,2\%), Veterinary Medicine (20; $22,5 \%)$ and Zootechny $(16 ; 18,0 \%)$.

However, when you highlight the productions that used humans as the study population $(25 ; 28,1 \%)$, the areas of training are different and diverse, including, in descending order of quantity of publications: Physical Education (12; 
48,0\%), Life Sciences (07; 28,0\%), Physiotherapy $(02 ; 8,0 \%)$, Pharmacy $(01 ; 4,0 \%)$, Medicine $(01$; $4,0 \%)$, Dentistry $(01 ; 4,0 \%)$ and Psychology $(1 ;$ $4,0 \%)$.
The list of local development of theses and dissertations can be viewed in Figure 1.

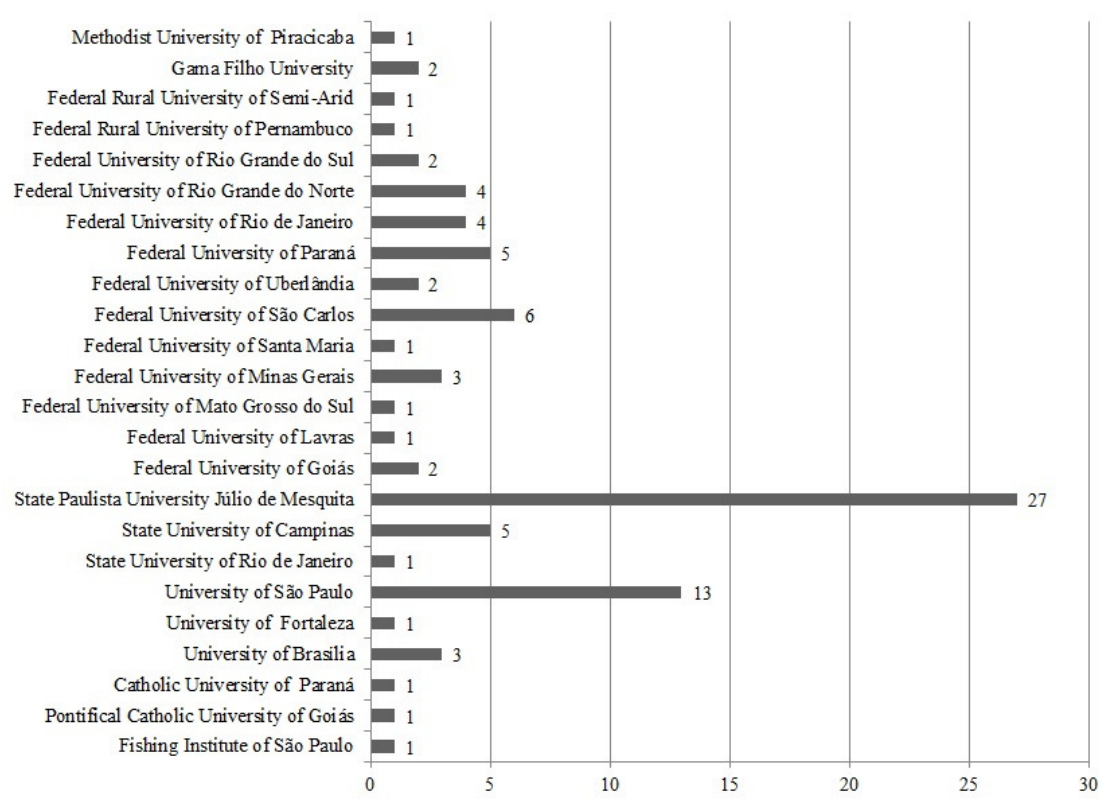

Figure 1. Local of development of dissertations and theses examined, in absolute numbers, 2013.

The Paulista State University Júlio de Mesquita Filho excelled in quantitative yields, with a total of $27(30,3 \%)$ developed investigations, followed by the University of São Paulo, where there were produced $13(14,7 \%)$ analyzed theses and dissertations.

Both universities are mentioned in the state of São Paulo, which was highlighted in the quantitative analysis of studies $(53 ; 60,4 \%)$. When grouping the studies in the Brazilian regions, highlighted, receives the Southeast, where they were produced $66(74,1 \%)$ studies, appearing soon after the South $(09 ; 10,1 \%)$ regions, the Midwest $(07$; $7,9 \%)$ and Northeast $(07 ; 7,9 \%)$. Therefore unmade works developed in the Brazilian Northern region.

The data exposing the populations studied in relation to the type of analysis of cortisol material are shown in Figure 2.

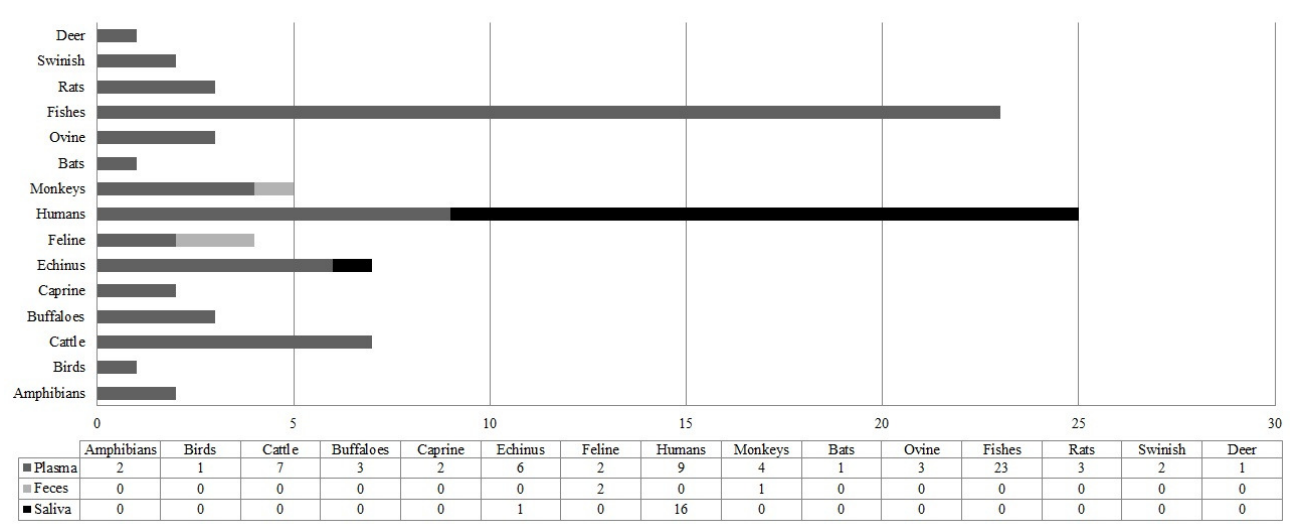

Figure 2. Cortisol analysis material versus population studied in dissertations and examined theses, in absolute numbers, 2013.

Therefore, there is the largest number of studies in humans $(25 ; 28,1 \%)$ and fish $(23 ; 25,8 \%)$. With regard to research involving humans, the following populations were covered: professional athletes $(12 ; 48,0 \%)$ - cyclists, swimmers, pilots, athletes, bodybuilding, soccer players, golfers, wrestlers karate and wrestling runners; patients $(04$; $16,0 \%)$, healthy volunteers $(03 ; 12,0 \%)$, students $(02 ; 8,0 \%)$, nurses $(01 ; 4,0 \%)$, children of parents with anxiety disorder $(01 ; 4,0 \%)$, executives $(01$; 
$4,0 \%)$ and caregivers of children with paralysis ( 01 ; $4,0 \%)$.

As for the material for analysis of cortisol, although the predominant use of blood plasma (69; $77,6 \%)$, and $17(19,1 \%)$ studies analyzed only three saliva $(3,3 \%)$ used investigations stool analysis. Regarding the analysis of the salivary cortisol of 17 $(100,0 \%)$ studies were performed with human 16 $(94,1 \%)$ and one $(5,9 \%)$ with horses.

A large proportion of studies $(83 ; 93,2 \%)$ reported using other materials for further analysis, encompassing mainly the physiological parameters (vital signs, blood cells, hormones, etc.), Behavioral parameters, imaging and examinations of bodily parts.

The human studies also reported the use of inventories, namely: the Inventory of Stress Symptoms of Lipp, the Perceived Stress Questionnaire (EOQ), and the Recovery Stress Questionnaire for Athletes (Sport RESTQ-76), List of Stress Symptoms Pre-Competitive (LSSPCI), the Existential Fear Scale (EME), among others.

The data on stress generator used in the study and the type of response resulting from the same are shown in Figure 3. Was considered a positive response studies in which the event of stress affected the level of cortisol significantly.

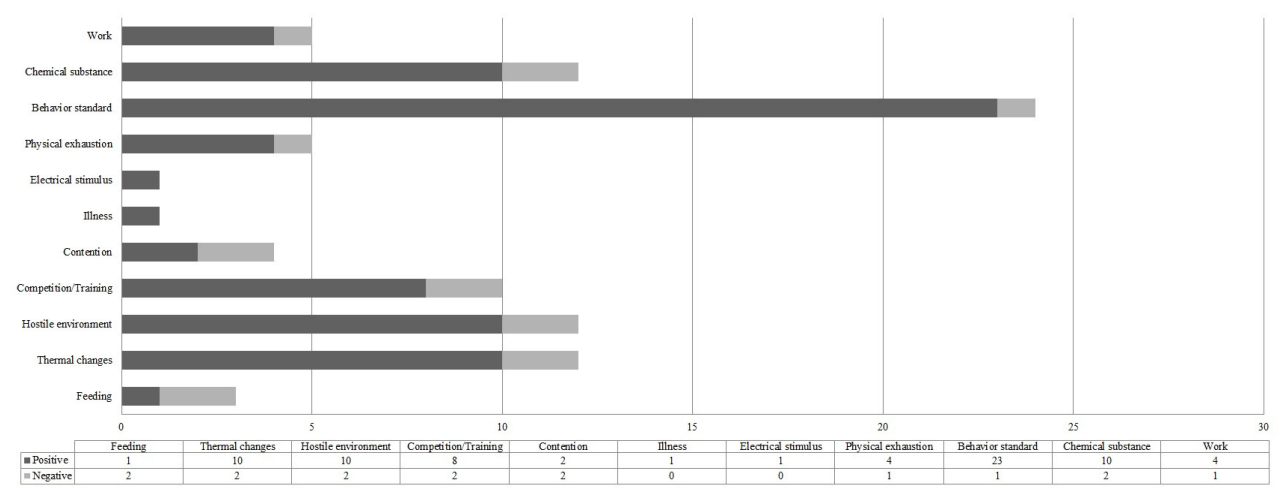

Figure 3. Response to cortisol versus stress generator used in dissertations and theses examined, in absolute numbers, 2013.

The highlights were the changes in the pattern of behavior as a generator element of stress $(24,27,0 \%)$, followed by: hostile environment $(12$, $13,5 \%)$, thermal changes $(12,13,5 \%)$ and chemical $(12,13,5 \%)$. Most studies denoted significant change in cortisol level by exposing the generating element of stress $(74,83,1 \%)$, revealing this to be a good marker of the stress response.

\section{DISCUSSION}

The research about cortisol as a marker of stress revealed an increasing number of scientific productions over the years, highlighting the increased production over the past 13 years. Increasing numbers of monographic studies on stress denote an imperative concern with the theme, this because the promotion of research, which focuses on sustaining economic growth and improving the quality of life is directly related to the everyday, oriented more immediate demands and the search for answers to universal questions (ROCHA NETO, 2010).

Thus, the research, which, since the 1970s, develops with great significance in Postgraduation, reflects the concern of professionals in responding to actual or potential problems, with the ultimate goal to focus on improvements, be they intellectual order or practice (GUIMARÃES, 2007; PIZZANI et al., 2012). Meanwhile, studies on stress and its mode of action and physiological reaction took place from the time this came to be regarded as the source of most of the morbidities and comorbidities in the current global context (JOCA; PADOVAN; GUIMARÃES, 2003).

Thus, the discovery of cortisol as a stress hormone levels stimulated discussion and debate this subject in order to elicit explanations, reflections, as well as the discovery of factors that are considered stressors, plotting ways for the prevention of pathological events associated with stress.

The quantitative analysis of dissertations and theses reflects this concern, in addition to match the current picture of Brazilian graduate, with a predominance of essays from academic courses MA and Ph.D., with a paucity of further studies following master courses, aspects also revealed in documentary searches similar (PIZZANI et al., 2012; SALVADOR et al., 2012).

It is known that the academic master, following a historical trend, is the type of 
postgraduate course that grows more and more headlines in the country, being the professional master incipient, forming no more than three thousand people per year (SCHWARTZMAN, 2010), although experienced significant growth today.

Another similar result to that found in other studies that examined Brazilian dissertations and theses (PIZZANI et al., 2012; RODRIGUES et al., 2012; SALVADOR et al, 2012; SANTOS, 2013) was the representativeness of studies in the Brazilian Southeast and, more specifically, in São Paulo.

Thus, the local development of research also reflects national stage productions those are mostly in the Southeast - space that houses $50,15 \%$ of total Brazilian stricto sensu courses - and in the South, especially the state of Sao Paulo, area of highest concentration of post-graduate courses in the Brazilian scenario. We see, therefore, a predominance of research that follows the same order of Brazilian federative regions with regard to the distribution of graduate programs in the country, according to the CAPES for the year 2012 (COORDINATION OF IMPROVEMENT OF HIGHER EDUCATION, 2012).

As for areas of expertise of the scholars who developed the studies analyzed, a dearth of research fostered by courses of biomedical area, with a predominance of Biological Sciences, Veterinary Medicine and Zootechny can be observed. It is of paramount importance to stress that health professionals are an important risk group for development of chronic stress, and result, ominously, the Burnout syndrome, also known as "burnout syndrome" experienced, especially among professionals who deal constantly with difficulties and problems of others, service situations, assisting and continuously work with humans, such as teachers and health professionals (PEREIRA et al., 2013).

In this context, it perceives the need to encourage research on stress also among researchers belonging to Biomedical, since; admittedly, the phenomenon of stress integrates their desktop, even if it adds little quantitative research undertaken in humans, who represented only $28,1 \%$ of the sample. We know the role sine qua non of animal research to generate results relevant to understanding the physiological stress and its consequences. However, when it highlights the complexity of the phenomenon in the human population, reveals the urgent need for development of human studies, particularly with professionals who represent risk groups for promotion of pathological events resulting from chronic stress.

Thus, it is essential to promote the development of research on human beings, so that they can contribute to identify the triggers and aggravating factors of stress and the influence of these at work and everyday life of the people, so that by identifying these conditions, draw up instruments and ways to prevent them (PEREIRA et al., 2013).

By analyzing the monographic research using cortisol as a marker of stress in humans, gave great representation of studies with athletes, an aspect that is also featured in the scientific literature (ARRUDA et al., 2013a; 2013b; COSWIG; NEVES; DEL VECCHIO, 2013; CRUZ et al., 2012; ROCHA; LOPES; MORAES, 2010; SILVA; MACEDO, 2011).

It is known that physical exercise and training process are classified as a stress to the human body. With regard to athletes, is emphatic that they are subjected to high loads of training, with the goal of improving performance and achieving desired competitive results, and experiencing different sources of stress associated not only to sports training itself, but also to other factors, such as pressure for results, interaction and daily life with peers, staff, leaders, media, fans, family, and others (ARRUDA et al., 2013b).

In this important assessment of this group of humans who are exposed to stressful events in greater magnitude scenario, the analysis becomes relevant in hormonal concentrations that can be correlated with the planning of training, because the increase in baseline testosterone indicates adequate training and recovery, while elevation of cortisol suggests organic overload and inadequate adjustment (COSWIG; NEVES; DEL VECCHIO, 2013).

Cortisol levels are thus linearly related to the intensity and duration of exercise (CRUZ et al., 2012), showing a positive relationship between testosterone levels and high degree of motivation and self-confidence, while the serum cortisol relates to anxiety and stress (COSWIG; NEVES; DEL VECCHIO, 2013).

In this context, studies that analyze the stress in athletes are highlighted and may contribute to define, with a lower degree of empiricism, the level of adaptation of these subjects to the training loads imposed (SILVA; MACEDO, 2011). In daily training, it is suggested that coaches, trainers and physiologists could adopt strategies to monitor immuno-endocrine responses, in association with use of psychometric instruments, with the aim of 
assisting the planning and adjusting training loads (ARRUDA et al., 2013a).

Stands out, once again, the importance of developing professional studies in the health field, as evidenced population already at risk for the disease by chronic stress (PEREIRA et al., 2013). In the sample of studies analyzed, only one Doctoral thesis in Psychology studied stress among nursing staff, indicating a strong relationship between cortisol levels and the diagnosis of Burnout syndrome.

It is known that there is environmental stress, biological and psychological outlook. However, the characteristics of the environment are the main influencing the increase in cortisol levels and as a consequence, determine biological and psychological changes in the body of subjects (CRUZ et al., 2012; ROCHA; LOPES; MORAES, 2010.).

This was a result observed in the analyzed theses and dissertations. For, from a population sample, the researchers created or simulated environments analyzed routine situations, noting that changes in the patterns of behavior and the environment are important elements that cause stress.

Thus, it is clarified that the environment is an important element can trigger stress and alter the physiology of the organism, both in animals and in humans (CRUZ et al., 2012; ROCHA; LOPES; MORAES, 2010.), revealing the importance promoting a healthy environment as a preventive factor of stress.

The studies placed emphasis on further confirmation that cortisol is a good marker of stress, indicating a positive association between stress level and exposure to the stressor in $83,1 \%$ of searches. This assertion was also highlighted in other studies, be asserting cortisol is a major physiological markers of stress (ARRUDA et al., 2013a; 2013b; CRUZ et al., 2012.).

Among the ways to analyze cortisol, the dissertations and theses revealed the serum, salivary and feces analysis, especially the first. In general, studies do not suggest preference of material for analysis, meeting those using blood cortisol (COSWIG; NEVES; DEL VECCHIO, 2013; CRUZ et al., 2012.), the salivary cortisol (ARRUDA et al., 2013a; 2013b; ROCHA; LOPES; MORAES, 2010), beyond the combined analysis of serum and salivary cortisol (PAZIKAS; CURI; AOKI, 2005).

However, researchers noted that most of the immunoassay methods used to determine the cortisol in the plasma, detects the total cortisol (bound and free), whereas cortisol concentration in urine and saliva quantify free cortisol. Thus, it is considered the salivary cortisol as an excellent index of free cortisol concentration (CASTRO; MOREIRA, 2003).

There are added, even as factors suggestive of the use of analysis of salivary cortisol in research: the measurement of salivary cortisol is independent of saliva flow rate and fluctuations of transcortin; saliva samples are obtained by simple, non-invasive procedure, stress-free, can be performed by untrained or ambulatory patient's own residence, the samples can be taken many times a day, enabling dynamic evaluation of secretion of free cortisol, and salivary cortisol samples are stable at room temperature environment for a week and can be transported to the laboratory by mail or carrier, without any loss of cortisol activity (CASTRO; MOREIRA, 2003).

Such questions, however, are assertions that reveal the quality and ease of use of the material for analysis of salivary cortisol, but do not exclude the possibility of using serum samples, urine and feces, which will depend on the characteristics of the population of study of each work. It was thus found no scientific evidence that encourages the use or disuse of either form of analysis of cortisol.

What was emphasized, however, was the use of supplementary materials and of standardized inventories for analysis of stress, together with cortisol as a physiological marker. The suggestion of the integrated stress analysis by combining multiple forms of assessment, highlight the complexity of the phenomenon, being used generally by researchers (ARRUDA et al, 2013a; 2013b; COSWIG; NEVES; DEL VECCHIO, 2013; CRUZ et al., 2012; PAZIKAS; CURI; AOKI, 2005; ROCHA; LOPES; MORAES, 2010).

It is understandable, therefore, that the physiological characteristics, such as the use of cortisol as a marker, are not isolated or independent generator psychological context of stress (ROCHA; LOPES; MORAES, 2010), therefore, is encouraging the use of multiple analysis forms the stressor, using psychometric instruments in conjunction with physiological parameters.

Finally, we highlight the essentiality of assessing the rate of publication in journals of the studies reviewed, suggestions for future analyzes, because, once unpublished works are restricted to the national level, limiting sometimes the advances that could provide for both professional awareness, and for investment planning and programs in the area (SALVADOR et al., 2012).

The discovery that cortisol is a marker of stress possible measure it, check and measure stress 
in different situations and environments, which carries a comprehensive ability to understand what can trigger increase or reduce stressful situations in daily life, and may also assist in the development of mechanisms for coping with stress.

Thus, it was noticed that there is a need to foster the development of clinical research with humans, since these, according to the literature, enable the expansion of more modern procedures and more specific findings that support the best man to live in society.

Furthermore, it is suggested the encouragement of research on stress in health professionals, recognized worldwide as an important group of risk population by chronic stress.

With the completion of this study has been impossible to reflect on the importance of analyzing the rate of publication of dissertations and theses in journals vehicle for dissemination of knowledge that allows the global dissemination of study results.

The sample reflects the national production on the use of cortisol as a marker of stress, which is seen as a limitation of the study, suggesting that future studies may examine similarities and differences in research in other countries.

RESUMO: Identificar em dissertações e teses disponíveis no Banco de Teses da Coordenação de Aperfeiçoamento de Pessoal de Nível Superior (CAPES) informações sobre os efeitos do cortisol enquanto marcador de estresse; caracterizar a amostra do estudo. Estudo de revisão bibliográfica narrativa, descritivo, cuja coleta de dados foi realizada em fevereiro de 2013, em pares, seguindo protocolo de pesquisa. Analisaram-se 89 dissertações e teses à luz dos pilares: nível acadêmico; local de desenvolvimento do estudo; ano; formação do autor; população estudada; elemento gerador do estresse; e material analisado. A maioria dos estudos denotou alteração significativa do nível de cortisol por meio da exposição ao elemento gerador do estresse $(74 ; 83,1 \%)$, revelando ser esse um bom marcador da resposta ao estresse. Percebeu-se que há necessidade de fomentar o desenvolvimento de pesquisas clínicas com seres humanos, em especial como profissionais de saúde.

PALAVRAS-CHAVES: Cortisol. Estresse Fisiológico. Avaliação da Pesquisa em Saúde.

\section{REFERENCES}

ARRUDA, A. F. S.; FREITAS, C. G.; MOURA, N. R.; AOKI, M. S.; MOREIRA, A. Resposta imunoendócrina associada à partida de futsal. Motriz, São Paulo, v. 19, p. 460-466, 2013 b.

http://dx.doi.org/10.1590/s1980-65742013000200023

ARRUDA, A. F. S.; MOREIRA, A.; NUNES, J. A.; VIVEIROS, S.; ROSE JR., D.; AOKI, M. S.

Monitoramento do nível de estresse de atletas da seleção brasileira de basquetebol feminino durante a preparação para a Copa América 2009. Revista Brasileira de Medicina do Esporte, São Paulo, v. 19, p. 4447, 2013a. http://dx.doi.org/10.1590/S1517-86922013000100009

CASTRO, M.; MOREIRA, A. C. Análise Crítica do Cortisol Salivar na Avaliação do Eixo HipotálamoHipófise-Adrenal. Arquivo Brasileiro de Endocrinologia e Metabolismo, São Paulo, v. 47, p. 358-367, 2003.

COORDINATION OF IMPROVEMENT OF HIGHER EDUCATION. Geocapes: dados estatísticos. 2012. Disponível em: <http://geocapes.capes.gov.br/geocapesds/\#>. Acesso em: 18 abr. 2014.

COSWIG, V. S.; NEVES, A. H. S.; DEL VECCHIO, F. B. Efeitos do tempo de prática nos parâmetros bioquímicos, hormonais e hematológicos de praticantes de jiu-jitsu brasileiro. Revista Andaluza de Medicina del Deporte, Andalucía, v. 6, p. 17-23, 2013. http://dx.doi.org/10.1016/S1888-7546(13)70030-3

CRUZ, I. S.; ROSA, G.; VALLE, V.; MELLO, D. B.; FORTES, M.; DANTAS, E. H. M. Efeitos agudos do treinamento concorrente sobre os níveis séricos de leptina e cortisol em adultos jovens sobrepesados. Revista Brasileira de Medicina do Esporte, São Paulo, v. 18, p. 81-86, 2012. http://dx.doi.org/10.1590/S151786922012000200003 
GUIMARÃES, R. O futuro da pós-graduação: avaliando a avaliação. Revista Brasileira de Pós-Graduação, Brasília, v. 4, p. 282-292, 2007.

JOCA, S. R. L.; PADOVAN, C. M.; GUIMARÃES, F. S. Estresse, depressão e hipocampo. Revista Brasileira de Psiquiatria, São Paulo, v. 25, p. 46-51, 2003. http://dx.doi.org/10.1590/S1516-44462003000600011

PAZIKAS, M. G. A.; CURI, A.; AOKI, M. S. Comportamento de variáveis fisiológicas em atletas de nado sincronizado durante uma sessão de treinamento na fase de preparação para as Olimpíadas de Atenas 2004. Revista Brasileira de Medicina do Esporte, São Paulo, v. 11, p. 357-362, 2005. http://dx.doi.org/10.1590/S1517-86922005000600010

PEREIRA, M. S.; SANTOS, N. P.; MARTINS, C. C. F.; SANTOS, V. E. P. Reflections of the burnout syndrome in physical and mental body of college professors. Revista de Enfermagem UFPE on line, Recife, v. 7, p. 4612-4620, 2013.

PIZZANI, L.; LOPES, J. F.; MANZINI, M. G.; MARTINEZ, M. C. S. Bibliometric analysis of theses and dissertations on prematurity in the Capes database. Jornal de Pediatria, Rio de Janeiro, v. 88, p. 479-482, 2012. http://dx.doi.org/10.2223/jped.2232

ROCHA, P. G. M.; LOPES, J. L.; MORAES, S. M. F. Efeito da Alteração Ambiental sobre Componentes Psicológicos e Parâmetros Fisiológicos durante Corrida em Atletas. Psicologia: Teoria e Pesquisa, Brasília, v. 26, p. 381-386, 2010. http://dx.doi.org/10.1590/S0102-37722010000200020

ROCHA NETO, I. Prospectiva da pós-graduação no Brasil (2008-2022). Revista Brasileira de PósGraduação, Brasília, v. 7, p. 58-79, 2010.

RODRIGUES, D. C.; BACKES, D. S.; FREITAS, H. M. B.; ZAMBERLAN, C.; GELHEN, M. H.; COLOMÉ, J. S. Conhecimentos produzidos acerca do crack: uma incursão nas dissertações e teses brasileiras. Ciência \& Saúde Coletiva, Rio de Janeiro, v. 17, p. 1247-1258, 2012. http://dx.doi.org/10.1590/S141381232012000500018

SAlVADOR, P. T. C. O.; ALVES, K. Y. A.; MARTINS, C. C. F.; SANTOS, V. E. P.; TOURINHO, F. S. V. Perfil das dissertações e teses brasileiras acerca do trauma: uma pesquisa documental. Revista do Colégio Brasileiro de Cirurgiões, Rio de Janeiro, v. 39, p. 328-334, 2012. http://dx.doi.org/10.1590/S010069912012000400014

SANTOS, L. M. A. Panorama das pesquisas sobre TDIC e formação de professores de língua inglesa em LA: um levantamento bibliográfico a partir da base de dissertações/teses da CAPES. Revista Brasileira de Linguística Aplicada, Belo Horizonte, v. 13, p. 15-36, 2013. http://dx.doi.org/10.1590/S198463982013000100002

SCHWARTZMAN, S. A transição necessária da pós-graduação brasileira. 2010. Disponível em: <http://www.jornaldaciencia.org.br/Detalhe.jsp?id=70462>. Acesso em: 18 abr. 2014.

SEVERINO, A. J. Metodologia do trabalho científico. 23. ed. São Paulo: Cortez, 2007.

SILVA, F. O. C.; MACEDO, D. V. Exercício físico, processo inflamatório e adaptação: uma visão geral. Revista Brasileira de Cineantropometria e Desempenho Humano, Florianópolis, v. 13, p. 320-328, 2011. 